\title{
PENGEMBANGAN BAHAN AJAR PENDIDIKAN AGAMA ISLAM BERBASIS PROBLEM BASED LEARNING UNTUK MENANGKAL RADIKALISME PADA PESERTA DIDIK SMA NEGERI DI KOTA BANDAR LAMPUNG
}

\author{
Imam Syafei \\ imamsyafei@ radenintan.ac.id \\ UIN Raden Intan Lampung
}

\begin{abstract}
Through the development of Islamic religious education teaching materials based on problem based learning, it is expected to further enhance the knowledge of Islamic religion of students, so that it is easier for these students to ward off radicalism. The purpose of this study (i) how is the development of Islamic religious education teaching materials based on problem based learning to counteract radicalism in students? (2) how is the effectiveness of Islamic religious education teaching materials based on problem based learning to ward off radicalism in students? So that the main objective in this research is to develop Islamic religious education teaching materials based on problem based learning, so as to ward off radicalism in high school students in Bandar Lampung City. This study uses research and development design, with a sample of 30 high school students in Bandar Lampung, part of the experimental class as a control class. Data collection techniques using questionnaires and documents. The data obtained were then analyzed using gain analysis and independent sample t test. The conclusions of the study are (1) the realization of the development of Islamic religious education teaching materials based on problem based learning to counteract radicalism in high school students in Bandar Lampung City. (2) there is a difference in the attitude of radicalism of students who use it and those who do not use teaching materials based on problem-based Islamic education in state high schools in Bandar Lampung City.
\end{abstract}

Keywords: Islamic religious education teaching materials, problem based learning, radicalism

\begin{abstract}
Melalui pengembangan bahan ajar pendidikan agama Islam berbasis problem based learning diharapkan semakin meningkatkan pengetahuan agama Islam peserta didik, sehingga semakin mudah bagi peserta didik tersebut menangkal radikalisme. Tujuan dari penelitian ini (i) bagaimana pengembangan bahan ajar pendidikan agama Islam berbasis problem based learning untuk menangkal radikalisme pada peserta didik? (2) bagaimana efektivitas bahan ajar pendidikan agama Islam berbasis problem based learning untuk menangkal radikalisme pada peserta didik? Sehingga tujuan utama dalam penelitian ini adalah untuk mengembangkan bahan ajar pendidikan agama Islam berbasis problem based learning, sehingga dapat menangkal radikalisme pada peserta didik SMA Negeri di Kota Bandar Lampung. Penelitian ini menggunakan desain research and development, dengan sampel 30 orang peserta didik SMA di Bandar Lampung sebagian kelas eksperimen sebagai kelas kontrol. Teknik pengumpulan data menggunakan angket dan dokumen. Data yang telah diperoleh kemudian dianalisis dengan menggunakan analisis gain dan independent sample $t$ test. Kesimpulan penelitian adalah (1) terwujudnya pengembangan bahan ajar pendidikan agama Islam berbasis problem based learning untuk menangkal radikalisme pada peserta didik SMA Negeri di Kota Bandar Lampung. (2) adanya perbedaan sikap radikalisme peserta didik yang menggunakan dengan yang tidak menggunakan bahan ajar pendidikan agama Islam berbasis problem based learning di SMA Negeri di Kota Bandar Lampung.
\end{abstract}

Kata Kunci: bahan ajar pendidikan agama Islam, problem based learninig, radikalisme 


\section{PENDAHULUAN}

Guru adalah fasilitator bagi peserta didik dalam memahami setiap materi yang diajarkan untuk mencapai kompetensi secara optimal. (Zein, 2016) Guru hendaknya mampu mengusahakan sumber belajar yang kiranya berguna serta dapat menunjang pencapaian tujuan dan proses belajar mengajar, baik yang berupa narasumber, buku teks, majalah, ataupun surat kabar. (Kirom, 2017) Salah satu upaya yang dapat dilakukan guru dalam membantu peserta didik memahami materi dengan lebih baik adalah dengan menggunakan bahan ajar. Bahan ajar dalam konteks kurikulum 2013 telah disediakan dalam bentuk buku teks namun menurut Yunus Abidin, meskipun terdapat buku peserta didik yang telah disediakan, guru masih mengkreasi dan mengembangkannya agar peserta didik tidak cenderung terpaku pada satu sumber belajar saja karena hal ini bertentangan dengan tujuan kurikulum yaitu membentuk lulusan yang kreatif, kritis, dan multiprespektif. (Abidin, 2014)

Bahan ajar adalah segala bentuk bahan yang digunakan untuk membantu guru/instruktur dalam melaksanakan kegiatan belajar mengajar di kelas, baik berupa bahan tertulis seperti hand out, buku, modul, lembar kerja mahasiswa, brosur, leaflet, wallchart, maupun bahan tidak tertulis seperti video/film, VCD, radio, kaset, CD interaktif berbasis komputer dan internet.(Arsant, 2018). Bahan ajar adalah unsur penting dalam pembelajaran. Dari bahan ajar tersebut guru dapat melaksanakan pembelajaran dan peserta didik terbantu dalam memahami materi pelajaran dengan lebih baik. Penyusunan bahan ajar bertujuan untuk 1) menyediakan bahan ajar yang sesuai dengan tuntutan kurikulum dengan mempertimbangkan kebutuhan peserta didik, sekolah, dan daerah, 2) membantu peserta didik dalam memperoleh alternatif bahan ajar, dan 3) memudahkan guru dalam melaksanakan pembelajaran”.(Depdiknas, 2008)

Berdasarkan pendapat tersebut dapat dipahami bahwa melalui bahan ajar, aktivitas dan kreatifitas peserta didik dalam pembelajaran dapat ditingkatkan, penyampaian materi pelajaran dapat dipermudah dengan menggunakan bahan ajar. Penggunaan bahan ajar dalam pembelajaran dapat mendorong peserta didik untuk belajar secara mandiri, belajar memahami dan menjalankan suatu tugas tertulis. Begitu juga dalam pembelajaran pendidikan agama Islam, kedudukan bahan ajar sangatlah penting agar peserta didik lebih mudah memahami materi pelajaran agama Islam dengan lebih baik. Untuk level Sekolah Menengah Atas (SMA) ada tiga buku ajar 
Pendidikan Agama Islam (PAI) untuk masing-masing kelas yang berbeda satu sama lain. Untuk kelas X digunakan buku Pendidikan Agama Islam yang disesuaikan dengan kompetensi yang akan dicapai pada kelas tersebut. Hal yang sama juga berlaku di kelas $\mathrm{X}$ dan XI.

Setiap bahan ajar pendidikan agama Islam tersebut hendaknya selaras dan mendukung tujuan pendidikan Islam dan tujuan pendidikan nasional. Tujuan pendidikan agama Islam adalah pembinaan kepribadian anak didik yang sempurna, peningkatan moral, tingkah laku yang baik dan menanamkan rasa kepercayaan anak terhadap agama dan kepada Tuhan, serta mengembangkan intelegensi anak secara efektif agar mereka siap untuk mewujudkan kebahagiaannya di masa mendatang. (Arief, 2002) Begitu juga tujuan pendidikan nasional dinyatakan dalam Undang Undang Nomor 20 Tahun 2003 tentang Sistem Pendidikan Nasional pada pasal 13 bahwa pendidikan nasional bertujuan untuk berkembangnya potensi peserta didik agar menjadi manusia yang beriman dan bertakwa kepada Tuhan Yang Maha Esa, berakhlak mulia, sehat, berilmu, cakap, kreatif, mandiri, dan menjadi warga negara yang demokratis serta bertanggung jawab.(Depdiknas, 2003). Berdasarkan tujuan pendidikan agama Islam dan tujuan pendidikan nasional tersebut dipahami bahwa pendidikan di Indonesia harus mampu menciptakan generasi yang memiliki akhlak mulia. Apalagi dalam pembelajaran pendidikan agama Islam, mendidik akhlak peserta didik merupakan tujuan pertama dan utama. Akan tetapi menanggapi isu-isu belakangan ini mengenai radikalisme dalam agama yang marak timbul dan berkembang pada peserta didik di tingkat SMA sangatlah memprihatinkan. Sebagaimana hasil penelitian yang dilakukan oleh Lembaga Kajian Islam dan Perdamaian (LaKIP) Jakarta sungguh mengejutkan. Penelitian yang dilakukan antara Oktober 2010 hingga 2011 terhadap guru PAI dan peserta didik (SMP dan SMA) di Jabodetabek menunjukkan bahwa $49 \%$ peserta didik setuju dengan aksi radikalisme demi agama.(Rokhmad, 2012)

Selain itu pentingnya meneliti radikalisme di kalangan peserta didik tingkat SMA, dengan beberapa alasan yaitu: Pertama Kurikulum PAI beserta standar isi dan kompetensinya sangat dipengaruhi oleh kecenderungan paham yang diajarkan oleh para guru kepada para peserta didik. Kedua: Peserta didik SMA yang tidak memiliki background pendidikan agama (pesantren) sangat mudah terpengaruh oleh model-model Islam harfiah yang diajarkan oleh guru atau ustadz mereka.(Rokhmad, 2012). Ketiga: 
Praktek radikalisasi di lingkungan SMU terjadi melalui berbagai aktivitas dan budaya sekolah, baik dalam proses belajar mengajar, kebijakan sekolah maupun dalam kegiatan ekstrakurikuler. Kegiatan ekstrakurikuler memiliki pengaruh yang cukup kuat dalam memasukkan ideologi dan pemahaman radikal di kalangan pelajar.(Darraz, 2013). Hal ini juga diperkuat dengan sebuah riset yang dilakukan oleh Maarif Institute pada tahun 2001 tentang pemetaan problem radikalisme di SMU Negeri 4 Daerah Pandeglang, Cianjur, Yogyakarta dan Solo, menunjukkan bagaimana sekolah dapat menjadi tempat masuknya paham radikalisme. Keberadaan sekolah dan lembaga pendidikan sebagai ruang terbuka bagi semua organisasi-organisasi keagamaan seringkali dimanfaatkan oleh segelintir orang untuk memasukkan paham-paham keagamaan mereka mulai dari paham yang moderat hingga paham keagamaan yang radikal. Kondisi seperti ini mempunyai konsekuensi makin banyaknya peserta didik yang terpengaruh pada pahampaham radikal keagamaan.(AF, 2013)

Bahkan hasil penelitian Abu Rokhmad menemukan bahwa di dalam buku paket dan LKS pada mata pelajaran pendidikan agama Islam tingkat SMA banyak bermunculan berbagai statemen yang dapat mendorong peserta didik membenci atau anti terhadap agama dan bangsa lain. Tafsir soal Yahudi dan Nasrani, soal memilih pemimpin yang tidak boleh dari kalangan Yahudi dan Nasrani, kemunduran umat Islam disebabkan karena pengaruh Barat, dan nikah beda akan menjadi pintu masuk bagi munculnya sikap permusuhan terhadap agama lain. Sikap ini menjadi salah satu paham yang dijadikan landasan kaum radikal di kalangan umat Islam.(Rokhmad, 2012). Dalam harian Kompas, tanggal 2 April 2015 dinyatakan bahwa masuknya paham radikalisme dalam dunia pendidikan terbukti dengan ditemukannya muatan radikal pada buku ajar Pendidikan Agama Islam dan Budi Pekerti pada jenjang sekolah menengah. Dalam buku Pendidikan Agama Islam dan Budi Pekerti kelas XI, cetakan ke-1 pada bab tokohtokoh pembaharuan dunia Islam masa modern dinyatakan unsur radikal karena adanya pernyataan di dalamnya bahwa yang harus disembah hanyalah Allah SWT, dan orang yang menyembah selain Allah SWT, telah menjadi musyrik dan boleh dibunuh.

Banyak faktor yang menjadi penyebab terjadinya terorisme dan aksi radikalisme yang mengatasnamakan Islam sebagai panji jihadnya yaitu. Pertama, pembelajaran agama yang setengah-setengah melalui proses doktriner. Kedua, literal pemahaman agama yang hanya memahami kulit atau dasarnya saja. Ketiga, cenderung 
mengharamkan segala hal yang justru membuat umat Islam merasa berat. Memang menjadi hal yang kecil namun dampaknya bisa mempengaruhi tatanan dan pola kehidupan masyarakat yang awalnya harmonis menjadi fanatic. (Safuan, 2018). Hal di atas menggambarkan bahwa dunia pendidikan kini telah digerogoti paham radikal. Meski riset di atas sebenarnya masih bisa dipertanyakan kevalidannya begitupun dengan buku yang dikatakan mengandung unsur radikal masih bisa dipertanyakan. Radikal dalam arti apa?. Namun hal ini harus dijadikan alarm untuk mengantisipasi semakin banyaknya generasi muda yang menganut paham radikal tersebut.

Hasil wawancara peneliti dengan beberapa guru agama Islam pada beberapa SMA Negeri yang ada di Kota Bandar Lampung, sebagian besar guru tersebut menyatakan bahwa dalam buku pendidikan agama Islam terkadang ada beberapa materi yang apabila tidak dipahami dengan benar oleh guru agama Islam, akan memberikan celah untuk masuknya paham radikal dalam diri peserta didik. (wawancara, 2017) Selain itu di dalam buku ajar (buku paket dan LKS) yang digunakan peserta didik SMA Negeri di Kota Bandar Lampung ditemukan dorongan substantif yang mengajak peserta didik untuk mengutamakan toleransi, demokrasi, penghormatan terhadap orang lain di satu sisi, dan di sisi lain ada pula pemahaman yang mendorong peserta didik bersikap anti-Barat, anti-Yahudi dan Nasrani dan lain sebagainya. (Observasi, 2017) Sisi yang saling bertentangan ini membutuhkan kebijaksanaan guru untuk menjelaskannya secara utuh dan komprehensif.

Di sini peran guru sangat penting dalam upaya mencegah radikalisme agama di sekolah karena guru merupakan salah satu dari komponen pendidikan yang mampu memberikan pengaruh terhadap pola pikir siswa-siswinya, terutaman guru Pendidikan Agama Islam (PAI), yang dipandang sebagai sosok teladan bagi siswa-siswi yang sangat moderat dalam menyampaikan ajaran Agama Islam di sekolah. Pasalnya, dalam Permendikbud atau silabus yang telah ditetapkan oleh pemerintah yang kemudian dijadikan acuan dasar bagi Guru Pendidikan Agama Islam, materi pengajaran tidak mengandung unsur radikalisme. (Umro, 2017). Oleh karenanya, posisi guru sangat strategis untuk mempengaruhi pikiran para peserta didik, baik pengaruh positif maupun negatif. Untuk mengantisipasi penyebaran Islam radikal, para guru PAI mesti memiliki strategi paling tidak untuk menghambatnya. Berdasarkan hasil penelitian terdahulu dan hasil prasurvey yang dilakukan peneliti, kiranya penelitian ini sangatlah penting. 
Melalui pengembangan bahan ajar pendidikan agama Islam dengan harapan bahan ajar yang dikembangkan tersebut dapat membantu para guru PAI di tingkat SMA Negeri yang ada di Kota Bandar Lampung dalam menangkal berkembangnya paham radikal dalam diri peserta didiknya.

Pengembangan bahan ajar pendidikan Agama Islam dilakukan dengan menggunakan model problem based learning. Problem based learning merupakan pembelajaran yang menggunakan masalah sebagai langkah awal dalam mengumpulkan dan mengintegrasikan pengetahuan baru. Peserta didik diberikan permasalahan pada awal pelaksanaan pembelajaran oleh guru, selanjutnya selama pelaksanaan pembelajaran peserta didik memecahkannya yang akhirnya mengintegrasikan pengetahuan ke dalam bentuk laporan. Problem based learning dapat memberikan pemahaman pada peserta didik lebih mendalam dalam segi analisis teori maupun praktek, sehingga peserta didik terlatih untuk dapat menemukan konsep yang dipelajari secara menyeluruh (holistik), bermakna, otentik, dan aktif. Melalui pengembangan bahan ajar pendidikan agama Islam berbasis problem based learning diharapkan semakin meningkatkan pengetahuan agama Islam peserta didik. Hal ini dikarenakan semakin tinggi tingkat pemahaman peserta didik terhadap pengetahuan agama Islam, maka semakin mudah bagi peserta didik tersebut menangkal radikalisme. Sebagaimana hasil penelitian Irham yang menemukan bahwa jika pemahaman keagamaan sempit dan eksklusif tidak menutup kemungkinan akan cenderung lebih tertutup dan tidak menerima keragaman.(Irham, 2015) Penelitian Abu Rokhmad juga menemukan bahwa salah satu faktor yang dapat mempengaruhi persepsi mahapeserta didik pada gerakan radikalisme berbasis agama adalah tingkat pengetahuan agama.(Rokhmad, 2012) Penelitian Chang-Yau Hoon menemukan, pendidikan agama bisa membentuk dan memelihara budaya dan identitas. Pendidikan agama juga berperan membangun peserta didik agar mampu bernegosiasi dengan perbedaan.(Hoon, n.d.)

Berdasarkan hasil penelitian terdahulu tersebut, penting kiranya melakukan pengembangan bahan ajar pendidikan agama Islam berbasis problem based learning untuk menangkal radikalisme pada peserta didik SMA Negeri di Kota Bandar Lampung. Dengan kata lain, pengembangan bahan ajar pendidikan agama Islam berbasis problem based learning diharapkan dapat meningkatkan pemahaman peserta didik tentang apa yang mereka pelajari sehingga mereka dapat membantu mereka 
menangkal paham radikal masuk ke dalam diri mereka, khususnya pada peserta didik tingkat SMA Negeri di Kota Bandar Lampung. Kerangka pikir dalam penelitian ini adalah tujuan utama penelitian ini adalah mengembangkan bahan ajar pendidikan agama Islam berbasis problem based learning untuk menangkal radikalisme pada peserta didik SMA Negeri di Kota Bandar Lampung. Oleh karena itu input penelitian ini adalah (1) LKS PAI kurang sesuai dengan kebutuhan peserta didik dan PAI hanya sebatas sekumpulan soal dengan sedikit ringkasan materi. (2) Sikap radikalisme peserta didik cukup tinggi. Adapun proses penelitian ini adalah dengan melakukan eksperimen hasil pengembangan bahan ajar pendidikan agama Islam berbasis problem based learning untuk menangkal radikalisme pada peserta didik SMA Negeri di Kota Bandar Lampung. Dari hasil proses tersebut diharapkan ouput yang diperoleh adalah (1) bahan ajar PAI berbasis problem based learning (2) ketertarikan dan efektifitas bahan ajar PAI yang dikembangkan (3) menangkal sikap radikalisme peserta didik. Untuk itu rumusan hipotesis yang akan diuji dalam penelitian ini adalah "Adanya perbedaan sikap radikalisme peserta didik yang menggunakan dengan yang tidak menggunakan bahan ajar pendidikan Agama Islam berbasis problem based learning di SMA Negeri di Kota Bandar Lampung."

\section{Pengembangan Bahan Ajar}

Bahan ajar adalah seperangkat sarana atau alat pembelajaran yang berisikan materi pembelajaran, metode, batasan-batasan, dan cara mengevaluasi yang didesain secara sistematis dan menarik dalam rangka mencapai tujuan yang diharapkan, yaitu mencapai kompetensi atau subkompetensi dengan segala kompleksitasnya.(Lestari, 2013) Menurut Majid bahan ajar adalah segala bentuk bahan yang digunakan untuk membantu guru/instruktur dalam melaksanakan kegiatan belajar mengajar.(Majid, 2014) Menurut Prastowo, bahan ajar adalah segala bahan yang disusun secara sistematis, menonjolkan sosok utuh dan kompetensi yang akan dikuasai peserta didik serta digunakan dalam proses pembelajaran.(Prastowo, 2014)

Harjanto mengatakan bahan ajar merupakan bagian penting dalam pelaksanaan pendidikan di sekolah.(Jufni, Djailani, \& Ibrahim, 2015) Bahan ajar sangat penting artinya bagi guru maupun siswa dalam proses pembelajaran. Tanpa bahan ajar, guru akan kesulitan untuk meningkatkan efektivitas pembelajaran. Demikian pun bagi siswa, tanpa bahan ajar siswa akan mengalami kesulitan menyesuaikan diri dalam belajar, 
apalagi jika gurunya mengajarkan materi yang belum siswa pahami sama sekali. (Perwitasari, Akbar, \& Wahjoedi, 2018). Berdasarkan beberapa pengertian tersebut bahan ajar dapat diartikan sebagai segala bentuk bahan yang disusun secara sistematis yang memungkinkan peserta didik dapat belajar secara mandiri dan dirancang sesuai kurikulum yang berlaku. Dengan adanya bahan ajar, guru akan lebih runtut dalam mengajarkan materi kepada peserta didik dan tercapai semua kompetensi yang telah ditentukan sebelumnya. Dengan demikian bahan ajar merupakan bahan yang dirancang dan disusun secara sistematis sesuai kurikulum yang berlaku guna membantu guru dan peserta didik dalam melaksanakan proses pembelajaran dan diciptakan dalam rangka mencapai tujuan pembelajaran.

Beberapa hal yang harus diperhatikan dalam pengembangan bahan ajar yang mampu membuat peserta didik untuk belajar mandiri dan memperoleh ketuntasan dalam proses pembelajaran yaitu: (i). Memuat contoh-contoh dan ilustrasi yang menarik dalam rangka mendukung pemaparan materi pembelajaran. (ii). Memberikan kemungkinan bagi peserta didik untuk memberikan umpan balik atau mengukur penguasaannya terhadap materi yang diberikan dengan memberikan soal-soal latihan tugas, dan sejenisnya. (iii).Kontekstual, yaitu materi yang disajikan terkait dengan suasana atau konteks tugas dan lingkungan peserta didik. (iv). Bahasa yang digunakan cukup sederhana karena peserta didik hanya berhadapan dengan bahan ajar ketika belajar secara mandiri.(Chomsin S. Widodo dan Jasmadi, 2008)

Bahan ajar yang akan dikembangkan memiliki beberapa macam bentuk. Bentuk bahan ajar inilah yang akan digunakan sebagai acuan sifat bahan ajar yang akan dikembangkan. Pada umumnya bahan ajar dikelompokkan menjadi lima macam bentuk, yaitu (1) bahan ajar yang membantu peserta didik menemukan suatu konsep, (2) bahan ajar yang membantu peserta didik menerapkan dan mengintegrasikan berbagai konsep yang telah ditemukan, (3) bahan ajar yang berfungsi sebagai penuntun belajar, (4) bahan ajar yang berfungsi sebagai penguatan, dan (5) bahan ajar yang berfungsi sebagai petunjuk praktikum. (Prastowo, 2014). Berdasarkan pendapat tersebut, maka bahan ajar yang dikembangkan peneliti merupakan bahan ajar yang membantu peserta didik menemukan suatu konsep, serta bahan ajar yang membantu peserta didik menerapkan dan mengintegrasikan berbagai konsep yang telah ditemukan, baik integrasi dengan 
sains yang langsung berhubungan dengan materi yang dipelajari maupun dengan nilainilai moral.

\section{Radikalisme}

Radikalisme adalah paham atau aliran radikal. Radikal merupakan perubahan secara mendasar dan prinsip, atau dapat diartikan bahwa radikalisme berarti suatu konsep atau semangat yang berupaya mengadakan perubahan secara menyeluruh dan mendasar tanpa memperhitungkan adanya peraturan-peraturan atau ketentuan-ketentuan konstitusional, politis dan social yang berlaku. (Sesmiarni, 2015). Eggi Sudjana mengungkapkan jika istilah radikalisme sering disebut dengan istilah reaksioner. Menurutnya radikalisme merupakan sikap atau tindakan terhadap berbagai perubahan tatanan kehidupan yang sudah lama dan mapan (established). Perbedaan antara reaksioner dan radikalisme menurut Eggi Sudjana adalah pada aspek tujuannya. Kaum reaksioner menginginkan perubahan tatanan masyarakat dalam batas-batas tertentu dan masih mentolerir sebagian tatanan yang ada, sedangkan kaum radikalis justru mengingingkan perubahan tatanan yang ada ke akar-akarnya bahkan jika perlu dilakukan dengan kekerasan (revolusi berdarah). (Wiyani, 2013)

Radikalisme dapat diartikan sebagai sebuah paham atau aliran yang menginginkan perubahan atau pembaharuan sosial dan politik secara drastis dengan menggunakan cara-cara kekerasan.(http://artikata.com/arti-346678-radikalisme.html, n.d.) Makna radikalisme dalam sudut pandang keagamaan dapat diartikan sebagai paham keagamaan yang mengacu pada fondasi agama yang sangat mendasar dengan fanatisme keagamaan yang sangat tinggi, sehingga tidak jarang penganut paham/aliran tersebut menggunakan kekerasan untuk mengaktualisasikan paham keagamaan yang dianut dan diyakininya.(http://www.referensimakalah.com/2012/01/pengertianfundamentalisme-radikalisme_8767.html, n.d.) Proses yang terjadi dalam radikalisme adalah radikalisasi, yang didefinisikan sebagai proses personal di mana individu mengadopsi idealisme dan aspirasi politik, sosial, atau agama secara ekstrim, dimana dalam pencapaian tujuannya membenarkan penggunaan kekerasan tanpa pandang bulu, sehingga mempersiapkan dan memotivasi seseorang untuk mencapai perilaku kekerasan.(Dubouloz, 2009)

Berdasarkan beberapa pendapat tersebut dapat dipahami bahwa yang dimaksud radikalisme adalah suatu paham keagamaan yang mengacu pada fondasi agama yang 
sangat mendasar dengan fanatisme keagamaan yang sangat tinggi, dengan menggunakan kekerasan untuk mengaktualisasikan paham keagamaan yang dianut dan diyakininya tersebut. Beberapa ciri suatu gerakan radikalisme berbasis agama menurut Komaruddin Hidayat antara lain: Pertama: Para tutor penyebar ideologi kekerasan itu selalu menanamkan kebencian terhadap negara dan pemerintahan. Bahwa pemerintahan Indonesia itu pemerintahan taghut, syaitan, karena tidak menjadikan Alquran sebagai dasarnya. Pemerintahan manapun dan siapa pun yang tidak berpegang pada Alquran berarti melawan Tuhan dan mereka mesti dijauhi, atau bahkan dilawan. Kedua: Para peserta didik yang sudah masuk pada jaringan ini menolak menyanyikan lagu-lagu kebangsaan, terlebih lagi upacara hormat bendera. Kalaupun mereka melakukan, itu semata hanya untuk mencari selamat, tetapi hatinya mengumpat. Ketiga: Ikatan emosional pada ustaz, senior, dan kelompoknya lebih kuat daripada ikatan keluarga dan almamaternya. Keempat: Kegiatan yang mereka lakukan dalam melakukan pengajian dan kaderisasi bersifat tertutup dengan menggunakan lorong dan sudut-sudut sekolah, sehingga terkesan sedang studi kelompok. Lebih jauh lagi untuk pendalamannya mereka mengadakan outbond atau mereka sebut rihlah, dengan agenda utamanya renungan dan baiat. Keliam: Bagi mereka yang sudah masuk anggota jamaah diharuskan membayar uang sebagai pembersihan jiwa dari dosa-dosa yang mereka lalukan. Jika merasa besar dosanya, maka semakin besar pula uang penebusannya. Keenam: Ada di antara mereka yang mengenakan pakaian secara khas yang katanya sesuai ajaran Islam, serta bersikap sinis terhadap yang lain. Ketujuh: Umat Islam di luar kelompoknya dianggap fasik dan kafir sebelum melakukan hijrah: bergabung dengan mereka. Kedelapan: Mereka enggan dan menolak mendengarkan ceramah keagamaan di luar kelompoknya. Meskipun pengetahuan mereka tentang Alquran masih dangkal, namun mereka merasa memiliki keyakinan agama paling benar, sehingga meremehkan, bahkan membenci ustaz di luar kelompoknya. Kesembilan: Di antara mereka itu ada yang kemudian keluar setelah banyak bergaul, diskusi secara kritis dengan ustaz dan intelektual di luar kelompoknya, namun ada juga yang kemudian bersikukuh dengan keyakinannya sampai masuk ke perguruan tinggi.(Komaruddin Hidayat, n.d.)

\section{Problem Based Learning}

Trianto menyatakan bahwa problem based learning merupakan suatu model pembelajaran yang berdasarkan pada banyaknya permasalahan yang membutuhkan 
penyelidikan autentik. Penyelidikan autentik yaitu penyelidikan yang membutuhkan penyelesaian dari suatu permasalahan nyata. (Trianto, 2009) Menurut Nurhadi, problem based learning adalah pembelajaran yang menggunakan masalah yang ada di dunia nyata sebagai suatu konteks bagi peserta didik untuk belajar tentang cara berpikir kritis, kreatif dan terampil memecahkan masalah.(Burhan Yasin Nurhadi dan Agus Gerrad Senduk, 2004). Firmansyah mengatakan bahwa PBL merupakan model pembelajaran yang memberikan kesempatan peserta didik menggali pengalaman autentik sehingga mendorong mereka aktif belajar, mengkonstruksi pengetahuan, dan mengintegrasikan konteks belajar di sekolah dan kehidupan nyata secara ilmiah. Peserta didik tidak sekedar mendengarkan, mencatat, dan menghafal materi yang disampaikan oleh guru, tetapi diharapkan mampu berfikir, mencari, mengolah data, dan berkomunikasi dalam proses pembelajaran.(Fauzan, Gani, \& Syukri, 2017)

Pendapat lain dari Hung problem based learning adalah sebuah kurikulum yang merencanakan pembelajaran untuk mencapai suatu tujuan instuksional. PBL merupakan model pembelajaran yang menginisiasi siswa dengan menghadirkan sebuah masalah agar diselesaikan oleh siswa. Selama proses pemecahan masalah, siswa membangun pengetahuan serta mengembangkan keterampilan pemecahan masalah dan keterampilan self-regulated learner. Dalam proses pembelajaran PBL, seluruh kegiatan yang disusun oleh siswa harus bersifat sistematis. Hal tersebut diperlukan untuk memecahkan masalah atau menghadapi tantangan yang nanti diperlukan dalam karier dan kehidupan sehari- hari.(Shofiyah \& Wulandari, 2018)

Pemberian permasalahan yang riil akan merangsang rasa ingin tahu, keinginan untuk mengamati, serta keinginan untuk terlibat dalam suatu masalah akan semakin besar. Rasa keingintahuan sebuah permasalahan akan memicu siswa untuk ingin mempelajari dan memahami konsep sebagai bahan untuk mencari beberapa solusi sampai pada kesimpulan solusi yang tepat dalam memecahkan sebuah permasalahan. Konteks riil bukan hanya permasalahan yang terjadi di sekitar namun juga konteks dimana pengetahuan yang siswa pelajari dari sebuah permasalahan dapat digunakan. Jadi, ada keterkaitan antara masalah dengan materi pembelajaran. Tujuan dari ketepatan konteks sebuah permasalahan terhadap materi pembelajaran yaitu agar siswa dapat menggali, mempertahankan, dan menerapkan pengetahuannya dengan tepat. (Masholekhatin \& Handoyo, n.d.) 
Berdasarkan pengertian problem based learning dari beberapa ahli di atas, penulis menyimpulkan bahwa problem based learning merupakan pembelajaran yang memusatkan peserta didik pada suatu masalah nyata yang autentik dan bermakna untuk ditentukan pemecahan masalahnya. Oleh karena itu, peserta didik akan belajar menganalisis masalah secara logis, kreatif, dan kritis serta dapat menentukan pemecahan masalah yang bervariasi. Menurut Arends ada 5 langkah dalam melaksanakan pelajaran problem based learning, yaitu memberikan orientasi tentang permasalahannya kepada peserta didik, mengorganisasikan peserta didik untuk meneliti, membantu investigasi mandiri dan kelompok, mengembangkan dan mempresentasikan, menganalisis dan mengevaluasi proses mengatasi masalah.(Rahmawati \& Sukidjo, 2016). Menurut Trianto, tahapan untuk pembelajaran problem based learning dapat dilihat pada Tabel 2.1 berikut.(Trianto, 2009)

Tabel 1. Tahapan Pembelajaran Problem Based Learning

\begin{tabular}{|c|l|l|}
\hline No & \multicolumn{1}{|c|}{ Tahapan } & \multicolumn{1}{c|}{ Kegiatan Guru } \\
\hline 1 & $\begin{array}{l}\text { Orientasi peserta didik } \\
\text { pada masalah }\end{array}$ & $\begin{array}{l}\text { Guru membahas tujuan pembelajaran, hal-hal } \\
\text { yang dianggap perlu, dan memotivasi peserta } \\
\text { didik untuk terlibat dalam melakukan } \\
\text { kegiatan pemecahan masalah }\end{array}$ \\
\hline 2 & $\begin{array}{l}\text { Mengorganisasikan } \\
\text { peserta didik untuk } \\
\text { belajar }\end{array}$ & $\begin{array}{l}\text { Membagi peserta didik dalam kelompok dan } \\
\text { membantu peserta didik dalam } \\
\text { mengidentifikasi serta mengorganisasikan } \\
\text { tugas-tugas yang berkaitan dengan masalah }\end{array}$ \\
\hline 3 & $\begin{array}{l}\text { Membimbing } \\
\text { penyelidikan individu } \\
\text { maupun kelompok }\end{array}$ & $\begin{array}{l}\text { Mendorong peserta didik untuk } \\
\text { mengumpulkan informasi yang tepat, } \\
\text { melaksanakan eksperimen dan penyelidikan } \\
\text { untuk dapat menjelaskan dan memecahkan } \\
\text { masalah }\end{array}$ \\
\hline 4 & $\begin{array}{l}\text { Mengembangkan dan } \\
\text { menjelaskan hasil karya }\end{array}$ & $\begin{array}{l}\text { Membantu peserta didik dalam merencanakan } \\
\text { dan mempersiapakan karya yang sesuai } \\
\text { seperti laporan dan membantu mereka } \\
\text { menjelaskan berbagai tugas kepada temannya }\end{array}$ \\
\hline 5 & $\begin{array}{l}\text { Menganalisis dan } \\
\text { mengevaluasi proses } \\
\text { pemecahan masalah }\end{array}$ & $\begin{array}{l}\text { Membantu peserta didik untuk melakukan } \\
\text { refleksi atau evaluasi terhadap penyelidikanya } \\
\text { dan proses-proses yang mereka gunakan. }\end{array}$ \\
\hline
\end{tabular}

Berdasarkan beberapa pendapat tersebut dipahami bahwa pada prinsipnya langkah-langkah pembelajaran problem based learning diawali dengan pengenalan masalah kepada peserta didik, kemudian peserta didik diorganisasikan dalam beberapa kelompok untuk berdiskusi dan memecahkan masalah yang diberikan, selanjutnya hasil 
diskusi yang diperoleh dipresentasikan kepada kelompok lain dan guru sebagai fasilitator melakukan klarifikasi mengenai hasil diskusi yang diperoleh oleh setiap peserta didik.

\section{METODE PENELITIAN}

Penelitian ini menggunakan desain research and development, yaitu suatu proses yang digunakan untuk mengembangkan dan menvalidasi hasil suatu pendidikan. Pengembangan yang dimaksud adalah pengembangan bahan ajar pendidikan agama Islam berbasis problem based learning. Bahan ajar pendidikan agama Islam yang dikembangkan diharapkan dapat digunakan sebagai salah satu media pembelajaran dan efektif dalam menangkal radikalime, khususnya pada peserta didik tingkat SMA Negeri di Kota Bandar Lampung.

Desain penelitian pengembangan ini berdasarkan adaptasi langkah-langkah model pengembangan dari Borg and Gall. Langkah-langkah penelitian pengembangan yang dapat digunakan untuk penelitian dalam bidang pendidikan seperti yang dikemukakan oleh Borg and Gall dalam Sugiyono, adalah sebagai berikut.

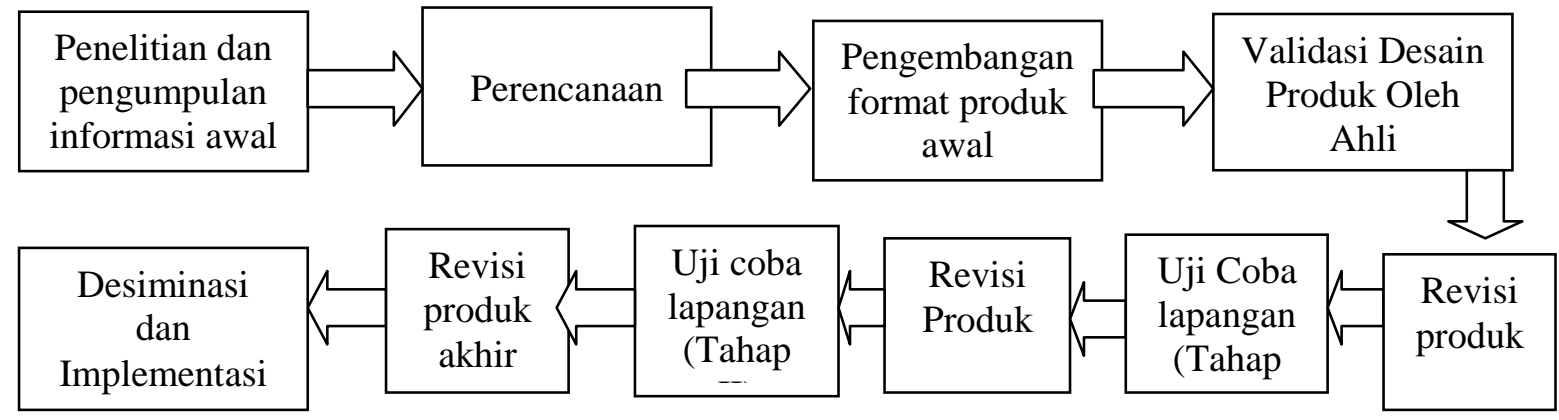

Gambar 3.1 Langkah-Langkah Penelitian Pengembangan

\section{Definisi Operasional Variabel Penelitian}

Pertama: Pengembangan bahan ajar pendidikan agama Islam berbasis problem based learning adalah mengembangkan bahan ajar pendidikan agama Islam dalam bentuk lembar kegiatan siswa (LKS) yang efektif melalui proses pembelajaran mengamati, menanya, mencoba, menalar, dan mengkomunikasikan hasil pembelajaran. Kedua: Radikalisme siswa adalah suatu pemahaman keagamaan siswa yang menggunakan kekerasan untuk mengaktualisasikan paham keagamaan yang dianut dan diyakininya tersebut. Pengukuran tingkat radikalisme siswa tersebut melalui angket 
dengan lima pilihan jawaban yang menggunakan skala Likert. Populasi dalam penelitian ini adalah seluruh peserta didik tingkat SMA Negeri di Kota Bandar Lampung pada tahun pelajaran 2018/2019 berjumlah 16.540 peserta didik yang tersebar dalam 17 sekolah. Sedangkan sampel dalam penelitian ini dipilih 2 sekolah, yaitu sebagai berikut:

Tabel 3.1

Sampel Penelitian

\begin{tabular}{|l|c|c|c|}
\hline \multicolumn{1}{|c|}{ Asal Sekolah } & Kelas & Sampel & Keterangan \\
\hline SMA Negeri 9 Bandar Lampung & XII IPS 1 & 30 & Kelas Eksperimen \\
\hline SMA Negeri 14 Bandar Lampung & XII IPS 1 & 30 & Kelas Kontrol \\
\hline
\end{tabular}

Teknik pengumpulan data yang dipergunakan dalam penelitian ini adalah teknik angket. Angket diberikan kepada peserta didik pada akhir pembelajaran untuk mengetahui tingkat radikalisme pada peserta didik. Skala yang digunakan adalah skala Likert dengan lima pilihan jawaban yaitu (1) Sangat Setuju, (2) Setuju, (3) Kurang Setuju, (4) Tidak Setuju, dan (5) Sangat Tidak Setuju. Teknik analisis data yang digunakan dalam penelitian ini menggunakan uji perbedaan dua rata-rata. Prosedur pengujian efektivitas pengembangan bahan ajar pendidikan agama Islam berbasis problem based learning untuk menangkal radikalisme pada peserta didik SMA dilakukan analisis data dengan teknik uji t independent (independent sample $t$ test) melalui analisis tingkat radikalisme peserta didik yang menggunakan dengan yang tidak menggunakan bahan ajar pendidikan agama Islam berbasis problem based learning.

\section{HASIL PENELITIAN DAN PEMBAHASAN}

Tahap awal Pengumpulan informasi awal dengan menganalisis kebutuhan peserta didik dan guru terhadap pengembangan bahan ajar pendidikan agama Islam berbasis problem based learning untuk menangkal radikalisme pada peserta didik SMA Negeri di Kota Bandar Lampung. Pada umumnya guru pendidikan agama Islam di SMA Negeri 9 Bandar Lampung dan SMA Negeri 14 Bandar Lampung menganggap perlunya dilakukan pengembangan LKS yang sesuai dengan kebutuhan dan karakteristik peserta didik, sehingga efektif dalam menangkal radikalisme pada peserta didik SMA Negeri di Kota Bandar Lampung. Sebagian besar peserta didik kelas XII IPS 1 di SMA Negeri 9 Bandar Lampung yang berjumlah 30 orang menyatakan bahwa mereka membutuhkan pengembangan LKS yang lebih menarik dan memudahkan mereka untuk memahami materi dengan lebih baik. Dengan demikian dapat disimpulkan bahwa pengembangan 
bahan ajar pendidikan agama Islam berbasis problem based learning dibutuhkan bagi peserta didik dalam upaya menangkal radikalisme pada peserta didik SMA Negeri di Kota Bandar Lampung.

Tahap kedua prencanaan; Pengembangan bahan ajar pendidikan agama Islam yang dilakukan dalam bentuk LKS. Pengembangan bahan ajar pendidikan agama Islam yang dilakukan berbasis problem based learning. Kurikulum yang digunakan dalam penelitian ini adalah kurikulum 2013, khususnya di kelas XII tingkat SMA pada semester ganjil yaitu pada Bab "Bersatu dalam Keragaman dan Demokrasi”. Setelah melakukan perencanaan langkah selanjutnya adalah pengembangan format produk awal bahan ajar berbasis problem based learning. Tahap ketiga: Uji coba awal diajukan kepada ahli materi dan ahli desain, yaitu dosen ahli materi dan ahli desain di UIN Raden Intan Lampung. Uji coba awal peneliti lakukan dengan cara memvalidasi 2 aspek, yaitu aspek desain dan aspek materi atau konten, oleh ahli materi pembelajaran. Validasi isi dilakukan oleh ahli yang kompeten terhadap LKS, materi PAI dan model pembelajaran.

Tahap Keempat: Revisi Produk; Hasil uji coba awal melalui validasi ahli materi dan ahli desain dilakukan revisi produk sebagai berikut: (i) Perbaiki cover LKS dengan tampilan yang lebih berwarna, sesuai dengan poko bahasan dan menggunakan gambar nyata; (ii) Perbaikan pendahuluan: Cantumkan langkah-langkah pembelajaran problem based learning; (iii) Perbaiki gambar yang digunakan dalam penyajian materi dengan gambar nyata agar peserta didik lebih mudah memahami gambar tersebut dengan lebih jelas; (iv) Perbaikan Isi: Cantumkan sumber pada gambar; (v) Perbaikan isi: sajikan masalah yang lebih kompleks yang mengembangkan aktvitas belajar peserta didik.

Tahap kelima; Uji Coba Lapangan (Tahap 1); Setelah dilakukan revisi produk atas saran tim ahli materi dan ahli desain, bahan ajar yang dikembangkan sudah siap untuk diujicobakan di lapangan pada lingkup kecil yaitu di 1 (satu) sekolah yaitu kelas XII IPS 1 di SMA Negeri 9 Bandar Lampung dengan jumlah peserta didik sebanyak 10 (sepuluh) orang peserta didik. Rata-rata penurunan sikap radikalisme peserta didik uji coba tahap I sebelum menggunakan bahan ajar PAI berbasis problem based learning sebesar 87,8. Setelah menggunakan bahan ajar PAI berbasis problem based learning, rata-rata penurunan sikap radikalisme peserta didik sebesar 110,2. Hasil tersebut membuktikan bahwa ada penurunan sikap radikalisme peserta didik uji coba tahap I setelah menggunakan bahan ajar PAI berbasis problem based learning. Artinya 
pengembangan bahan ajar PAI berbasis problem based learning dapat menangkal radikalisme pada peserta didik SMA Negeri di Kota Bandar Lampung khususnya di kelas XII IPS 1 SMA Negeri 9 Bandar Lampung. Tahap keenam Revisi Produk; Berdasarkan hasil uji coba produk tahap 1 tersebut dan hasil konsultasi dengan tim ahli materi dan ahli desain, maka tidak perlu dilakukan revisi produk. Oleh karena itu bahan ajar PAI berbasis problem based learning dapat langsung diujicobakan pada tahap ke-2 yang lebih luas yaitu di seluruh peserta didik kelas XII IPS 1 di SMA Negeri 9 Bandar Lampung yang berjumlah 30 orang peserta didik.

Tahap ketujuh: Uji Coba Lapangan (Tahap 2) Pada tahap II uji coba produk di lapangan dilaksanakan di kelas XII IPS 1 di SMA Negeri 9 Bandar Lampung dengan jumlah peserta didik 30 orang. Rata-rata penurunan sikap radikalisme peserta didik sebelum menggunakan bahan ajar PAI berbasis problem based learning sebesar 83,16667. Setelah menggunakan bahan ajar PAI berbasis problem based learning, ratarata sikap radikalisme peserta didik menurun sebesar 109,7. Hasil tersebut membuktikan bahwa ada penurunan sikap radikalisme peserta didik di kelas XII IPS 1 SMA Negeri 9 Bandar Lampung setelah menggunakan bahan ajar PAI berbasis problem based learning. Artinya pengembangan bahan ajar PAI berbasis problem based learning dapat menangkal radikalisme pada peserta didik SMA Negeri di Kota Bandar Lampung. Tahap kedelapan Revisi Produk Akhir; Berdasarkan hasil konsultasi kepada para ahli materi pelajaran dan ahli desain serta guru PAI, dengan melihat data hasil uji coba kelompok kecil (tahap I) dan kelompok besar (tahap II), maka disimpulkan bahwa bahan ajar PAI berbasis problem based learning ini tidak perlu dilakukan revisi dan layak untuk didesminasikan dan diimplementasikan. Tahap kesembilan: Implementasi Produk; Produk bahan ajar PAI berbasis problem based learning yang telah final kemudian diimplementasikan pada dua sekolah yaitu di SMA Negeri 9 Bandar Lampung dan SMA Negeri 14 Bandar Lampung. Implementasi produk ini dilakukan dengan sasaran yaitu kelas XII IPS 1 di SMA Negeri 9 Bandar Lampung yang berjumlah 30 peserta didik sebagai kelas eksperimen dan kelas XII IPS 1 di SMA Negeri 14 Bandar Lampung yang berjumlah 30 peserta didik sebagai kelas kontrol. 
Tabel 3.2

Distribusi Data Tingkat Radikalisme Peserta didik

\begin{tabular}{|l|c|c|}
\hline \multirow{2}{*}{ Aspek } & SMA N 9 Bandar Lampung & SMA N 14 Bandar Lampung \\
\cline { 2 - 3 } & Kelas Eksperimen & Kelas Kontrol \\
\hline $\mathrm{N}$ & 30 & 30 \\
\hline Mean & 109,70 & 89,43 \\
\hline Median & 113,00 & 89,00 \\
\hline Mode & 112 & 89 \\
\hline Minimum & 89 & 81 \\
\hline Maximum & 125 & 99 \\
\hline Sum & 3291 & 2683 \\
\hline
\end{tabular}

Sumber: Hasil pengolahan data melalui SPSS Versi 20,0.

Pada tabel tersebut, diketahui bahwa penurunan sikap radikalime peserta didik kelas XII IPS 1 di SMA Negeri 9 Bandar Lampung yang menggunakan bahan ajar pendidikan agama Islam berbasis problem based learning lebih besar dari sikap radikalime peserta didik kelas XII IPS 1 di SMA Negeri 14 Bandar Lampung yang tidak menggunakan LKS berbasis problem based learning.

Tabel 3.3

Hasil Pengujian Hipotesis

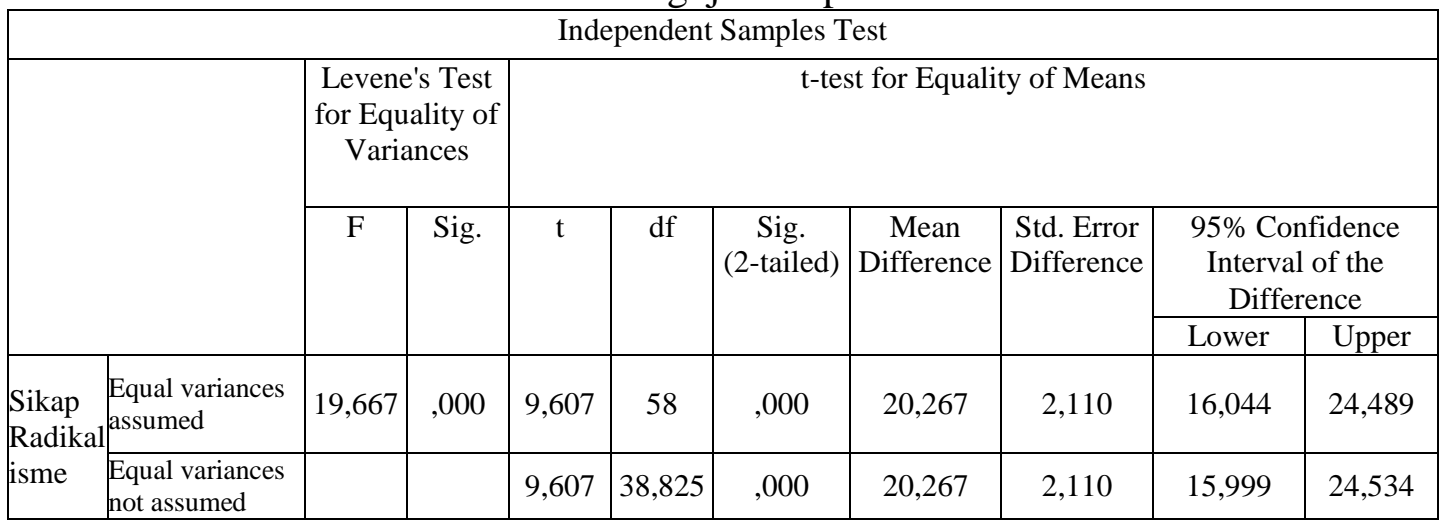

Sumber: Hasil pengolahan data melalui SPSS Versi 20,0.

Pada tabel tersebut, diperoleh data bahwa nilai $r_{\text {hitung }}$ sikap radikalime peserta didik lebih kecil dari nilai $\alpha$ yang digunakan $(0,05)$ yaitu $0,000<0,05$ yang diinterpertasikan bahwa adanya perbedaan sikap radikalisme peserta didik yang menggunakan dengan yang tidak menggunakan bahan ajar pendidikan agama Islam berbasis problem based learning di SMA Negeri di Kota Bandar Lampung.

Berdasarkan hasil pengujian hipotesis tersebut dapat disimpulkan bahwa hipotesis alternatif $(\mathrm{Ha})$ dalam penelitian ini diterima yaitu "Adanya perbedaan sikap 
radikalisme peserta didik yang menggunakan dengan yang tidak menggunakan bahan ajar pendidikan agama Islam berbasis problem based learning di SMA Negeri di Kota Bandar Lampung." Artinya penggunaan bahan ajar pendidikan agama Islam berbasis problem based learning dapat menangkal radikalisme pada peserta didik SMA Negeri di Kota Bandar Lampung. Hasil penelitian ini relevan dengan pendapat yang dikemukakan M.Taufiq Amir bahwa penerapan problem based learning memiliki beberapa kelebihan diantaranya yaitu meningkatkan kemampuan siswa dan mengembangkan keterampilan dan pengetahuan siswa untuk memecahkan masalah.(M.Taufiq Amir, 2010) Begitu pula Trianto juga menyatakan bahwa problem based learning memiliki banyak kelebihan diantaranya adalah meningkatkan kemampuan siswa dalam memahami materi dengan lebih baik.(Trianto, 2010)

Hasil penelitian ini juga relevan dengan hasil penelitian Nanang Budi Nugroho yang menemukan bahwa LKS berbasis problem based learning efektif dalam meningkatkan ketuntasan belajar siswa.(Nugroho, 2015) Relevan juga dengan hasil penelitian Khairul Anwar yang menemukan bahwa penggunaan model pembelajaran problem based learning dapat meningkatkan hasil belajar siswa.(Anwar, 2014). Penelitian Dyahna Ebtasari juga menemukan bahwa hasil belajar siswa kelas eksperimen yang menggunakan student worksheet berbasis problem based learning lebih baik daripada hasil belajar siswa kelas kontrol yang tidak menggunakan student worksheet berbasis problem based learning. (Dyahna Ebtasari, 2016) Hasil penelitian Eni Setianingsih juga mendukung hasil penelitian ini yang menemukan bahwa ada peningkatan hasil belajar antara sebelum dan setelah digunakan LKS berbasis problem based learning.(Setianingsih, 2017). Penelitian Husniati menemukan keefektifan modul berbasis PBL disertai diagram pohon ditunjukkan melalui $\mathrm{N}$-gain score termasuk kategori sedang $(0,41)$ dengan hasil belajar siswa setelah diberikan modul pembelajaran dengan nilai aspek kognitif termasuk kategori baik $(79,91)$, aspek psikomotorik temasuk kategori sangat baik (85), aspek afektif termasuk kategori sangat baik (91). (Husniati, 2016)

Berdasarkan hasil penelitian, teori, dan penelitian yang relevan dapat disimpulkan bahwa pengembangan bahan ajar pendidikan agama Islam berbasis problem based learning dapat menangkal radikalisme pada peserta didik SMA Negeri di Kota Bandar Lampung. Hal tersebut dibuktikan dengan adanya perbedaan tingkat 
radikalisme peserta didik yang menggunakan dengan yang tidak menggunakan bahan ajar pendidikan agama Islam berbasis problem based learning di SMA Negeri di Kota Bandar Lampung. Perbedaan tingkat radikalisme peserta didik tersebut menunjukkan penurunan tingkat radikalisme peserta didik yang signifikan setelah menggunakan bahan ajar pendidikan agama Islam berbasis problem based learning. Dengan demikian berdasarkan hasil penelitian ini dapat menjadi salah satu alternati bagi guru dalam menangkal radikalisme pada peserta didik SMA Negeri di Kota Bandar Lampung melalui penggunaan bahan ajar pendidikan agama Islam berbasis problem based learning yang dikembangkan.

\section{SIMPULAN DAN SARAN}

\section{Kesimpulan}

Berdasarkan hasil pengolahan dan analisis data maka diperoleh beberapa kesimpulan yaitu: Pertama: Terwujudnya pengembangan bahan ajar pendidikan agama Islam berbasis problem based learning untuk menangkal radikalisme pada peserta didik SMA Negeri di Kota Bandar Lampung. Kedua: Adanya perbedaan sikap radikalisme peserta didik yang menggunakan dengan yang tidak menggunakan bahan ajar pendidikan agama Islam berbasis problem based learning di SMA Negeri di Kota Bandar Lampung.

\section{Saran}

Berdasarkan simpulan tersebut dapat dikemukakan saran-saran sebagai berikut. Bagi peserta didik, bahan ajar pendidikan agama Islam berbasis problem based learning dapat mengembangkan kemampuan peserta didik dalam memahami materi lebih baik lagi, menangkal radikalisme pada peserta didik, dan mengembankan kemampuan berpikir ilmiah peserta didik. Bagi guru, bahan ajar pendidikan agama Islam berbasis problem based learning dapat dijadikan salah satu media dalam melaksanakan pembelajaran dan solusi dalam menangkal radikalisme pada peserta didik. Bagi sekolah, bahan ajar pendidikan agama Islam berbasis problem based learning dapat meningkatkan kualitas dan kuantitas pembelajaran dan hasil belajar peserta didik, sehingga mutu pendidikan sekolah semakin meningkat. Bagi peneliti lain, bahan ajar pendidikan agama Islam berbasis problem based learning sebagai salah satu acuan dan menambah rujukan dalam penelitian selanjutnya 


\section{DAFTAR PUSTAKA}

Abidin, Y. (2014). Desain Sistem Pembelajaran Dalam Konteks Kurikulum 2013. Bandung: Pt. Refika Aditama.

Af, A. G. (2013). Pemetaan Problem Radikalisme Di Smu Negeri Di 4 Daerah. Jurnal Maarif, 8(1), 172.

Anwar, K. (2014). Meningkatkan Hasil Belajar Siswa Melalui Model Pembelajaran Problem Based Learning Pada Pelajaran Ipa Materi Pokok Zat Dan Wujudnya Di Kelas Iv Sd Negeri 064977 Bhayangkara T.P. 2013/2014. Jurnal Pgsd Universitas Negeri Medan, 2(1), 45 - 54.

Arief, A. (2002). Ilmu Dan Metodologi Pendidikan Islam. Jakarta: Ciputat Pers.

Arsant, M. (2018). Pengembangan Bahan Ajar Mata Kuliah Penulisan Kreatif Bermuatan Nilai-Nilai Pendidikan Karakter Religius Bagi Mahasiswa Prodi Pbsi , Fkip, Unissula. Jurnal Kredo, 1 No. 2, 74.

Burhan Yasin Nurhadi Dan Agus Gerrad Senduk. (2004). Pendekatan Kontekstual. Surabaya: Publisher.

Chomsin S. Widodo Dan Jasmadi. (2008). Panduan Menyusun Bahan Ajar Berbasis Kompetensi. Jakarta: Pt. Elex Media Komputindo.

Darraz, M. A. (2013). Radikalisme Dan Lemahnya Peran Pendidikan Kewargaan. Jurnal Maarif, 8(1), 14.

Depdiknas. (2003). Undang Undang Nomor 20 Tahun 2003 Tentang Sistem Pendidikan Nasional. Jakarta: Depdiknas.

Depdiknas. (2008). Pedoman Penyusunan Lks Sd/Mi (Depdiknas, Ed.). Jakarta.

Dubouloz, W. And. (2009). Homegrown Terrorism And Transformative Learning : An Interdisciplinary Approach To Understanding Radicalization. Ottawae: Canadian Political Science Association Conferenc.

Dyahna Ebtasari. (2016). Pengembangan Student Worksheet Berbasis Problem Based Learning Untuk Meningkatkan Kemampuan Berpikir Kritis Siswa Pada Mata Pelajaran Teknik Kerja Bengkel Di Smk Negeri 7 Surabaya. Jurnal Pendidikan Teknik Elektro Universitas Negeri Surabaya, 5(3), 925 - 943.

Fauzan, M., Gani, A., \& Syukri, M. (2017). Penerapan Model Problem Based Learning Pada Pembelajaran Materi Sistem Tata Surya Untuk Meningkatkan Hasil Belajar Siswa. Jurnal Pendidikan Sains Indonesia, 5(1), 29.

Hoon, C.-Y. (N.D.). Mapping "Chinese" Christian Schools In Indonesia: Ethnicity, Class And Religion. Journal Asia Pacific Education, 403.

Http://Artikata.Com/Arti-346678-Radikalisme.Html. (N.D.).

Http://Www.Referensimakalah.Com/2012/01/Pengertian-FundamentalismeRadikalisme_8767.Html. (N.D.).

Husniati. (2016). Pengembangan Modul Berbasis Problem Based Learning (Pbl) Disertai Diagram Pohon Pada Materi Fotosintesis Kelas Viii Smp Negeri 1 Sawoo. Jurnal Prosiding Seminar Nasional Biologi Universitas Negeri Surabaya, 2(1), $453-470$.

Irham. (2015). Pesantren Dan Perkembangan Politik Pendidikan Agama Di Indonesia. Jurnal Pendidikan Agama Islam Ta'lim Universitas Pendidikan Indonesia, 13(1), 95.

Jufni, M., Djailani, A., \& Ibrahim, S. (2015). Kreativitas Guru Pai Dalam Pengembangan Bahan Ajar Di Madrasah Aliyah Jeumala Amal Lueng Putu. Jurnal Administrasi Pendidikan Pascasarjana Universitas Syiah Kuala, 3(4), 65. 
Kirom, A. (2017). Peran Guru Dan Peserta Didik Dalam Proses Pembelajaran Berbasis Multikultural Askhabul. Al-Murabbi: Jurnal Pendidikan Agama Islam, 3 No. 1, 74.

Komaruddin Hidayat. (N.D.). Radikalisme Islam Menyusup Ke Smu, Http://Www.UinSy.Co.Id.

Lestari, I. (2013). Pengembangan Bahan Ajar Berbasis Kompetensi. Jakarta: Akademia Permata.

M.Taufiq Amir. (2010). Inovasi Pendidikan Melalui Problem Based Learning: Bagaimana Pendidik Memberdayakan Pembelajaran Di Era Pengetahuan. Jakarta: Kencana Prenada Media Group.

Majid, A. (2014). Pembelajaran Tematik Integratif Terpadu. Bandung: Pt. Remaja Rosdakarya.

Masholekhatin, N. S., \& Handoyo, B. (N.D.). Pengaruh Model Pembelajaran Problem Based Learning ( Pbl) Terhadap Hasil Belajar Geografi. 2.

Nugroho, N. B. (2015). Pengembangan Rpp Dan Lks Berbasis Problem Based Learning Pada Materi Himpunan Untuk Siswa Smp Kelas Vii. E-Journal Universitas Negeri Yogyakarta, 1(1), 96 - 118.

Observasi. (2017). Hasil Prasurvey Bahan Ajar Pendidikan Agama Islam Di Tingkat Sma Yang Digunakan Peserta Didik Sma Di Provinsi Lampung.

Perwitasari, S., Akbar, S., \& Wahjoedi. (2018). Pengembangan Bahan Ajar Tematik Berbasis Kontekstual. Jurnal Pendidikan: Teori, Penelitian, Dan Pengembangan, $3(3), 278$.

Prastowo, A. (2014). Paradigma Baru Madrasah Dalam Implementasi Kebijakan Kurikulum 2013. Jurnal Pendidikan Islam, Iiii(1), 95-114. Https://Doi.Org/10.14421/Jpi.2014.31.95-113

Rahmawati, R. I. A., \& Sukidjo. (2016). Pengembangan Bahan Ajar Berbasis Pbl Pada Pelajaran Ekonomi Untuk Meningkatkan Keterampilan Sosial Peserta Didik Sma. Jurnal Ilmu-Ilmu Sosial, 13(2), 118.

Rokhmad, A. (2012). Radikalisme Islam Dan Upaya Deradikalisasi Paham Radikal. Jurnal Walisongo Universitas Islam Negeri Walisongo Semarang, 20(1), 81.

Safuan, M. (2018). Menangkal Radikalisme Melalui Nilai-Nilai Luhur Kearifan Budaya Lokal. 1.

Sesmiarni, Z. (2015). Membendung Radikalisme Dalam Dunia Pendidikan Melalui Pendekatan Brain Based Learning. Kalam: Jurnal Studi Agama Dan Pemikiran Islam, 9(2), 235.

Setianingsih, E. (2017). Pengembangan Lembar Kegiatan Siswa Berbasis Model Problem Based Learning Pada Mata Pelajaran Ips Kelas Iv Di Gugus Antasari Kecamatan Gunung Sugih. Tesis. Bandar Lampung. Fakultas Keguruan Dan Ilmu Pendidikan Universitas Lampung Bandar Lampung.

Shofiyah, N., \& Wulandari, F. E. (2018). Model Problem Based Learning ( Pbl ) Dalam Melatih Scientific Reasoning Siswa. Jurnal Penelitian Pendidikan Ipa, 3(1), 34.

Trianto. (2009). Mendesain Model Pembelajaran Inovatif - Progresif. Konsep Landasan Dan Implementasi Pada Kurikulum Tingkat Satuan Pendidikan (Ktsp). Jakarta: Kencana Media Grup.

Trianto. (2010). Model-Model Pembelajaran Inovatif Berorientasi Konstruktivistik. Jakarta: Katalog Dalam Terbitan.

Umro, J. (2017). Upaya Guru Pendidikan Agama Islam Dalam Mencegah Radikalisme Agama Di Sekolah. Journal Of Islamic Education (Jie), 2(1), 91. 
Al-Tadzkiyyah: Jurnal Pendidikan Islam, Volume 10. No. I 2019 P. ISSN: 20869118

E-ISSN: 2528-2476

Wawancara. (2017). Hasil Prasurvey Bahan Ajar Pendidikan Agama Islam Di Tingkat Sma Yang Digunakan Peserta Didik Sma Di Provinsi Lampung.

Wiyani, N. A. (2013). Pendidikan Agama Islam Berbasis Anti Terorisme Di Sma. Jurnal Pendidikan Islam ::, 2(1), 67. Https://Doi.Org/10.14421/Jpi.2013.21.65-83

Zein, M. (2016). Peran Guru Dalam Pengembangan Pembelajaran. Jurnal Pendoidikan, $5(2), 274-2852$. 